\title{
Turkish Fathers' Utterance Complexity during the Interaction of Toy Play with Their Preschoolers*
}

\author{
Özge Cengiz \\ Department of Foreign Language Education, Istanbul Medeniyet University, Istanbul, Turkey \\ Email: ozge.cengiz@medniyet.edu.tr
}

Received 4 March 2016; accepted 15 April 2016; published 18 April 2016

Copyright () 2016 by author and Scientific Research Publishing Inc.

This work is licensed under the Creative Commons Attribution International License (CC BY). http://creativecommons.org/licenses/by/4.0/

(c) (i) Open Access

\section{Abstract}

There has been little research on the contributions of paternal language to their young children. Particularly father education may influence the quantity and the quality of father-child interactions (Pancsofar \& Vernon-Feagans, 2010). Focusing on the link between fathers' socioeconomic status (SES) and their language input, this research aims to investigate how fathers' SES influences their utterance complexity in the toy play context with their young children. Ten fathers differing in SES and their preschoolers were taped in their homes for about 15 minutes and fathers were asked to help their child during the toy play sessions. Research on fathers, though limited (Cabrera et al., 2007) has shown that father education is positively associated with children's language development. Since very few studies have considered the possible contributions of paternal language to children's early language development, this study examines the father-child dialogues and focuses on both fathers' and their children's language use. In this respect, this cross-sectional study tries to explore the father-child interactional patterns in terms of both fathers' and their children's utterance complexity, and reveal to what extent the linguistic contributions of fathers differentiate depending on their SES. The results indicate that SES has an important role in language use; that is, the utterances of high SES fathers and children are more complex and longer than their low SES counterparts.

\section{Keywords}

Paternal Language Input, Father-Child Interactions, Utterance Complexity, Mean Length of Utterance

\section{Introduction}

Language develops in the context of social relations and has its roots in the early interactions between children

${ }^{*}$ This article is a revised version of a paper presented at the Akdeniz Language Studies Conference. 
and their parents (Bruner, 1981; Tomasello, 1992). Although parent-child language interactions have been considered an important context of early language development, too few studies have examined fathers' language input (Pancsofar \& Vernon-Feagans, 2006). As has been found in research on mother education (Hoff, 2006), father education may also make important contributions to child language development. Over the last few decades there has been growing interest in research on fathers, and studies have shown that fathers' engagement with their children is related to children's language, literacy and cognitive skills (Tamis-LeMonda, Shannon, Cabrera, \& Lamb, 2004; Duursma, Pan, \& Raikes, 2008).

Several studies have also found links between SES and early language development (Fish \& Pinkerman, 2003; Hoff-Ginsberg, 1998). Hoff-Ginsberg (1998) has found that high-SES families used a richer vocabulary of object labels than did children from mid-SES families. Hart \& Risley (1995) and Hoff (2003) have found links between SES, vocabulary and mean length of utterance during parent-child interactions (Pancsofar \& VernonFeagans, 2006).

In Turkey, although there are studies concerning fathers' attitude towards child care and perceptions of their fathering roles (e.g. Bekman, 2001; Fişek, 2001; Taşkın \& Erkan, 2009), there is almost no research on the properties of paternal language use. This cross-sectional study focuses on the link between fathers' SES and their language input, in particular, their utterance complexity, i.e. mean length of utterance. Mean length of utterance (MLU) is a measure of linguistic productivity and the average number of morphemes per utterance. A higher MLU is taken to indicate a higher level of language proficiency (Brown, 1973). In addition to fathers, this study examines the MLU of these fathers' children as well. According to Brown (1973: p. 53), "MLU is an excellent simple index of grammatical development because almost every new kind of knowledge increases length".

While previous studies on parent-child interaction investigated parents' language use in contexts like bookreading, meal time and dressing (Hoff-Ginsberg, 1991; Bus, van Ijzendoorn, \& Pellegrini, 1995; Reese \& Cox, 1999; Ekmekçi \& Keşli, 2001; Zevenbergen \& Whitehurst, 2003; Küntay \& Ahtam, 2004; Türkay, 2007; Cengiz, 2010), this study aims to investigate the properties of paternal language use by examining the interaction between fathers and their preschoolers in the context of toy play.

When children enter school, they are expected to deal with a new language register which differs from the language used at home. This register is cognitively high demanding. In order to be successful at school, children are expected to organize knowledge in certain ways. Therefore, the characteristic of language used at home has an important role in children's organization of knowledge and linguistic development. However, the way of interaction between parents and their children and the language input that the parents provide may differ among families. Family SES is one of the variables that cause this difference. As mentioned before, studies have revealed links between SES and children's linguistic development (Fish \& Pinkerman, 2003; Hart \& Risley, 1995). Several studies have indicated that young children in higher quality child care have stronger and receptive language skills (NICHD Early Child Care Research Network, 2002). Higher quality child care predicts higher measures of language development (Burchinal et al., 2000). Heath (1983) and Ninio (1980) also indicated that parents from low SES talk much less to their children than high SES parents.

Within the framework outlined so far, this study has been designed to develop an overview of linguistic development in the preschool years with a particular focus on paternal language. It tries to build upon the previous research on paternal language input and the relation between fathers' SES and their utterance complexity in the context of toy play. The following research question guides this study:

What kind of, if any, SES-related differences are found between fathers' and also their children's utterance complexity, i.e. mean length of utterance, in the context of toy play?

\section{Method}

\subsection{Participants}

Ten fathers and their five-year old preschoolers participated in this study. Families were married, with both parents living in the home. They all lived in İzmir and were native Turkish speakers. Table 1 presents and overviews the characteristics of the participants. Low SES families had a primary or secondary school education, and lived in suburban areas, whereas high SES families had graduated from college or received a master's degree/PhD, and lived in more affluent districts of İzmir. All children attended nursery schools in their neighborhoods on weekdays. 
Table 1. Demographic characteristics of fathers.

\begin{tabular}{|c|c|c|c|c|c|}
\hline \multicolumn{2}{|l|}{ Fathers } & Age & Father's education & Father's employment & Family monthly income \\
\hline \multirow{5}{*}{ High SES } & 1 & 34 & College graduate & businessman & more than 3000 TL (\$1050) \\
\hline & 2 & 36 & Master's degree & engineer & more than 3000 TL ( $\$ 1050)$ \\
\hline & 3 & 34 & College graduate & bank employer & more than 3000 TL (\$1050) \\
\hline & 4 & 34 & College graduate & instructor & more than 3000 TL (\$1050) \\
\hline & 5 & 35 & $\mathrm{PhD}$ & Assist. Prof. & more than 3000 TL (\$1050) \\
\hline \multirow{5}{*}{ Low SES } & 1 & 32 & Primary school graduate & worker & less than 1000 TL (\$350) \\
\hline & 2 & 48 & Secondary school graduate & self-employed & less than 1000 TL (\$350) \\
\hline & 3 & 29 & Primary school graduate & worker & less than $1000 \mathrm{TL}(\$ 350)$ \\
\hline & 4 & 54 & Secondary school graduate & TV repairman & less than 1000 TL (\$350) \\
\hline & 5 & 38 & Primary school graduate & self-employed & less than 1000 TL (\$350) \\
\hline
\end{tabular}

The father participants ranged in age from 29 to 54 years, with a mean of 37.4 years. The average age of high SES fathers was 34.6 and that of low SES fathers was 40.2. While low SES fathers had a primary or secondary school education, high SES fathers had completed four years of college $(n=3)$ or received a master's $(n=1)$ or doctoral degree $(n=1)$. The fathers were employed outside of the home.

\subsection{Data Collection Procedure}

Participants were selected by means of purposive and snowball sampling methods. The reason for the small number of participants is that fathers had little or no incentive to attend, or were not available due to their working hours. Difficulties in recruitment of fathers were also caused by suspicion of a project on testing intelligence. Therefore, mothers were enlisted to encourage their partners to participate. Mothers' encouragement and information on the study helped to ensure father participation. After obtaining the participants' consent to contribute to the research, the families were visited at home by the researcher.

Before the observational session, each father was interviewed regarding his education, age and employment. The fathers' gender, age, education and monthly income were recorded. After the interview process, each father-child dyad was invited into a separate room. The picture in Figure 1 was shown to the father-child dyads and they were told either to use the blocks to build what they saw in the picture or that they were free to construct whatever they wanted with the building blocks.

As illustrated in Figure 1, the toys used in this context were building blocks with a set of wooden blocks. The blocks had different colors and shapes and contained a little bell, ramps and glass marbles.

Fathers were instructed to play with their children for about 15 minutes the way they usually would do with the building blocks provided by the researcher. The father-child dyads sat on the floor during the play session. The researcher placed two voice recorders on the floor and were not present in the room during the recording in order to make the fathers and children feel comfortable. Recording started when they had settled in the room, which was approximately one minute after they came into the room. If the child was distracted from playing or not willing to play, they were allowed to terminate the session and leave the room. Contrarily, the children were very interested in the toys and wanted to play with their fathers.

\subsection{Transcription of Speech}

All fathers and their five-year old preschoolers showed an interest in the interactive toy play session. Each interaction lasted between 06:00 and 36:00 minutes $(M=15: 00 \mathrm{~min}$.). These interactions were taped and transcribed. The flow of speech for fathers and their children was divided into utterances. An utterance is a conversational turn that contains one or more syntactic units (e.g. blue, square block, under the bell, the marble is going down the ramp) and it is usually preceded and followed by a change of turn in a conversation (Brown, 1973; Huttenlocher 


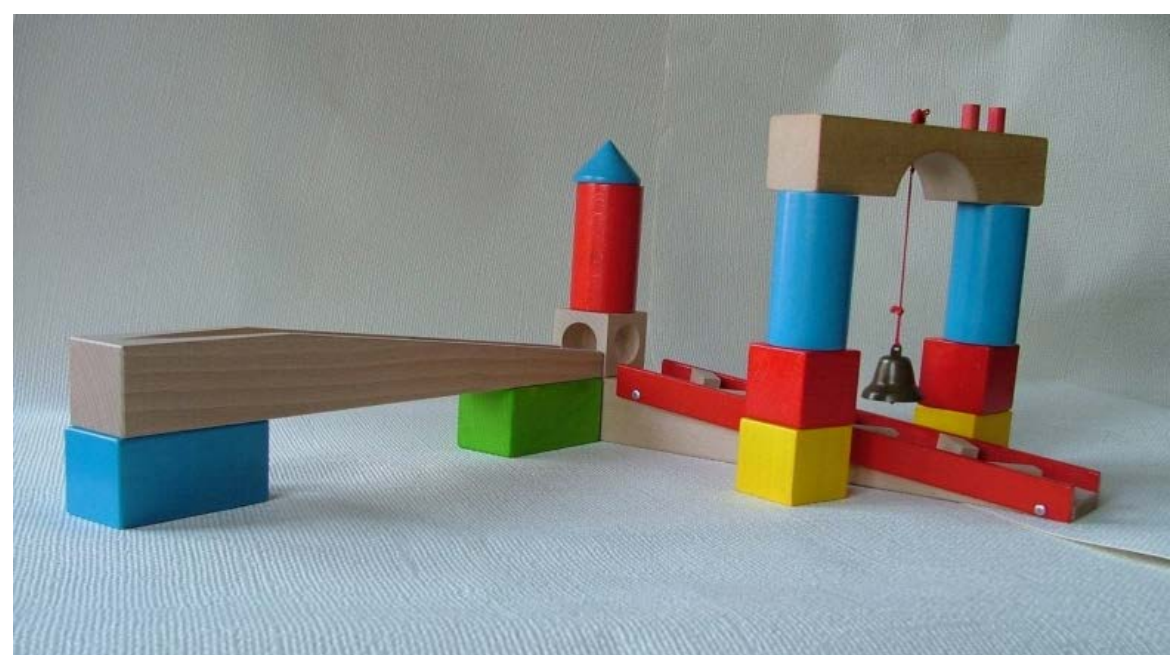

Figure 1. Toy Blocks used in the study.

et al., 2010). Two or more independent clauses occurring within the same conversational turn were considered as separate utterances.

\subsection{Analysis of Speech}

After the transcription process, total numbers of both fathers' and their children's utterances and morphemes were counted and the mean length of their utterances was calculated. After counting the morphemes for each of the father's and their children's utterances, they were divided by the total number of their utterances. The formula is as follows (Brown, 1973):

$$
\text { MLU }=\frac{\text { Total number of morphemes }}{\text { Total number of utterances }}
$$

Statistics were performed on the results to determine significance levels. Since the sample size of the study was small, a nonparametric test, two-independent-sample test, Mann Whitney U was applied using SPSS statistical packages (version 13.0). Statistical significance for all measures was deemed at $p<0.05$ based on two-independent-sample test.

\section{Results}

This study aimed to examine the link between fathers' SES and their utterance complexity in the context of toy play during the preschool period of their children. We were also interested in the utterance complexity of these fathers' children. In order to reveal fathers' and children's utterance complexity, we examined and counted their numbers of utterances and morphemes. Figure 2 presents the mean length of utterance of the fathers and their children during the toy play session.

As illustrated in Figure 2, the mean length of utterance value for high SES fathers $(M=5.2)$ was higher than the mean length of utterance value for low SES fathers $(M=3.6)$. Similarly, the mean length of utterance score for high SES children $(M=3.8)$ was higher than the mean length of utterance score for low SES children $(M=$ 3). Descriptive statistics on the mean length of utterances of fathers is given in Table 2.

As shown in Table 2, there was a difference between the mean length of utterance for low SES fathers and high SES fathers. The comparison of high SES and low SES fathers' MLU was significant $(p=0.006<0.05)$. Thus, high SES fathers had a higher mean length of utterance during their interaction with their children. Table 3 illustrates the descriptive statistics on the mean length of utterance of children.

According to the results presented in Table 3, the difference between the mean length of utterance for high SES and low SES children was statistically significant $(p=0.014<0.05)$. This shows that high SES children's mean length of utterance was higher while playing with their fathers. 


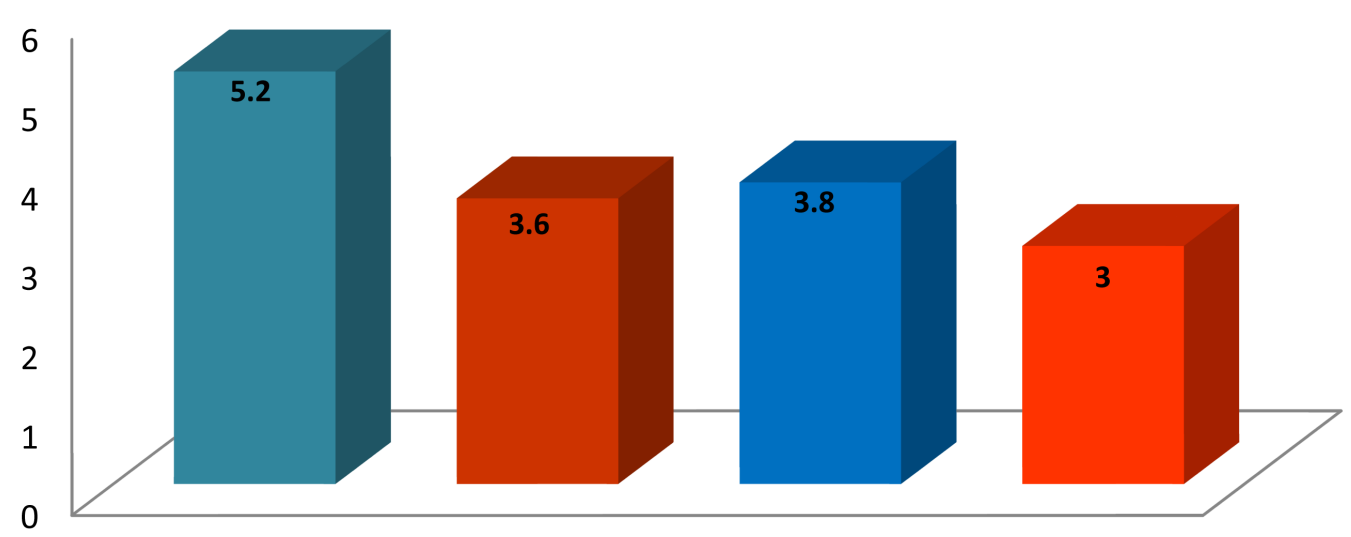

High SES Fathers Low SES Fathers High SES Children Low SES Children

Figure 2. Mean length of utterance of fathers and children.

Table 2. Descriptive statistics of fathers’ MLU.

(a)

\begin{tabular}{ccccc}
\hline & & \multicolumn{3}{c}{ Ranks } \\
\cline { 2 - 4 } & Group & N & Mean Rank & Sum of Ranks \\
\hline Mean Length of Utterance & Low SES Fathers & 5 & 3.00 & 15.00 \\
& High SES Fathers & 5 & 8.00 & 40.00 \\
\hline
\end{tabular}

(b)

\begin{tabular}{cc|}
\hline & Test Statistics $^{\mathbf{b}}$ \\
\hline Mann-Whitney U & Total_OQ \\
\hline Wilcoxon W & 0.000 \\
Z & 15.000 \\
Asymp.Sig. (2-tailed) & -2.739 \\
Exact Sig. [2*(1-tailed Sig.)] & 0.006 \\
\hline
\end{tabular}

${ }^{\mathrm{a}}$ Not corrected for ties; ${ }^{\mathrm{b}}$ Grouping Variable: Group_No.

\section{Discussion}

This study investigated fathers' and their preschoolers' language use, in particular, their utterance complexity in the context of toy play. The results showed that there are SES-related differences between fathers' and also their children's mean length of utterances. The findings revealed that both high SES fathers and their children produced more complex and longer utterances compared with their low SES counterparts. Previous study suggests that the interactions between parents and their children shape early language development. The present study aiming to more fully include fathers in the discourse surrounding parental language input has tried to build upon the previous research on fathers' language input, and has revealed that high SES families' children have produced more complex and longer utterances just as their fathers have done.

The findings of this study are in accord with previous findings. Fish \& Pinkerman (2003) and Hoff-Ginsberg (1998) have found links between family SES and linguistic development. Hoff-Ginsberg (1998) has also found that high SES families used a richer vocabulary. Hart \& Risley (1995) and Hoff (2004) have investigated parent-child interactions and have found links between SES and MLU (Pancsofar \& Vernon-Feagans, 2006). Since 
Table 3. Descriptive statistics of children's MLU.

(a)

\begin{tabular}{ccccc}
\hline & \multicolumn{3}{c}{ Ranks } \\
\cline { 2 - 4 } & Group & N & Mean Rank & Sum of Ranks \\
\hline Mean Length of Utterance & Low SES Children & 5 & 3.50 & 7.50 \\
& High SES Children & 5 & 7.50 & 37.50 \\
\hline
\end{tabular}

(b)

\begin{tabular}{cc}
\hline & Test Statistics $^{\mathbf{b}}$ \\
\hline Mann-Whitney U & Total_OQ \\
\hline Wilcoxon W & 2.500 \\
Z & 17.500 \\
Asymp.Sig. (2-tailed) & -2.449 \\
Exact Sig. [2*(1-tailed Sig.)] & 0.014 \\
\hline
\end{tabular}

${ }^{\mathrm{a}}$ Not corrected for ties; ${ }^{\mathrm{b}}$ Grouping Variable: Group_No.

it is well-established that family SES is a powerful predictor of many aspects of child development and particularly of children's linguistic development, our data seem to support the idea that fathers' SES influences their children's language development.

\section{Conclusion}

Almost all research on parent-child interactions has focused on mothers, not fathers. Over the last few decades, there has been growing interest in research on fathers. The present study specifically focused on the language use of fathers, particularly, their utterance complexity. The findings of this study showed not only high SES fathers but high SES children also produced more complex and longer utterances. From the above discussion, it can be said that besides mothers, fathers also make important contributions to their children. Parental level of education plays an important role in children's linguistic development. Since there has been a very limited number of studies on the contribution of fathers' language input, future research is needed to include fathers and explore the effects of their language use more deeply. Rather than just including mothers, fathers should also be included in all efforts to improve language development and school readiness. An important recommendation for researchers is that both parents should be educated on becoming more challenging partners with their preschoolers. Challenging speech makes meaningful contributions to the early language development of children, so parents should be stimulated to pay more attention to the language used at home. As mentioned earlier, before formal schooling starts, the characteristics of language used at home has an important role in preschoolers' linguistic development. More aware parents will help their children do better at school.

This study was limited in that sample size ( $\mathrm{n}=10$ dyads) was small. Another limitation was the non-homogeneity of fathers' personal characteristics, their ages and jobs. Furthermore, this study looked at the paternal language only within the context of toy play and in terms of utterance complexity, i.e. MLU. The length of time fathers normally shared with their children was not taken into consideration either. Since it was a cross-sectional study and the sample was not representative especially with regard to fathers' personal characteristics, their ages and jobs, the fathers cannot be generalized to the general population of fathers.

\section{Acknowledgements}

This study is the result of great effort on the part of many people. I thank the families who agreed to take part in this research. Without their cooperation, this study would not have been possible. 


\section{References}

Bekman, S. (2001). Çocuğun yaşamında babanın rolü ve önemi sempozyum raporu (Symposium Report on the Role of the Father in Child's Life). İstanbul: Anne Çocuk Eğitim Vakfı Yayını.

Brown, R. (1973). A First Language: The Early Stages. Cambridge, MA: Harvard University Press. http://dx.doi.org/10.4159/harvard.9780674732469

Bruner, J. (1981). The Social Context of Language Acquisition. Language and Communication, 1, 155-178. http://dx.doi.org/10.1016/0271-5309(81)90010-0

Burchinal, M. R., Roberts, J. E., Riggins, R., Zeisel, S. A., Neebe, E., \& Bryant, D. (2000). Relating Quality of Center-Based Child Care to Early Cognitive and Language Development Longitudinally. Child Development, 71, 339-357. http://dx.doi.org/10.1111/1467-8624.00149

Bus, A., van Ijzendoorn, M., \& Pellegrini, A. (1995). Joint Book Reading Makes for Success in Learning to Read: A Meta-Analysis on Intergenerational Transmission of Literacy. Review of Educational Research, 65, 1-21. http://dx.doi.org/10.3102/00346543065001001

Cabrera, N. J., Shannon, J. D., \& Tamis-LeMonda, C. (2007). Fathers İnfluence on Their Children's Cognitive and Emotional Development: From Toddler to Pre-K. Applied Developmental Science, 11, 208-213. http://dx.doi.org/10.1080/10888690701762100

Cengiz, Ö. (2010). Türk Annelerin Çocuklarına Kitap Okurken Kullandıkları Dilsel Kodlar ve Etkileşim Biçemi.(The Linguistic Codes and the Types of Verbal Interactions of Turkish Mothers in the Context of Shared Book Reading). Unpublished Doctoral Dissertation, İzmir: Dokuz Eylül University.

Duursma, E., Pan, B. A., \& Raikes, H. (2008). Predictors and Outcomes of Low-Income Fathers’ Reading with Their Toddlers. Early Childhood Research Quarterly, 23, 351-365. http://dx.doi.org/10.1016/j.ecresq.2008.06.001

Ekmekçi, Ö., \& Keşli, Y. (2001). Türk Çocuklarının Anadil Edinimindeki Edimblimsel Gelişmeleri. Dilbilim Kurultayı Bildirileri (pp. 251-256). İstanbul: Yıldız Teknik Üniversitesi Yayınları.

Fişek, G. (2001). Değişik açılardan babanın çocuk gelişimindeki rolü ve önemi. Çocuğun yaşamında babanın rolü ve önemi sempozyum raporu. İstanbul: Anne Çocuk Eğitim Vakfı Yayını.

Fish, M., \& Pinkerman, B. (2003). Language Skills in Low-SES Rural Appalachian Children: Normative Development and Individual Differences, Infancy to Preschool. Journal of Applied Developmental Psychology, 23, 539-565. http://dx.doi.org/10.1016/S0193-3973(02)00141-7

Hart, B., \& Risley, T. (1995). Meaningful Differences in the Everyday Experience of Young American Children. Baltimore, MD: Brookes.

Heath, S. B. (1983). Ways with Words: Language, Life, and Work in Communities and Classrooms. Cambridge: Cambridge University Press.

Hoff, E. (2003). The Specificity of Environmental Influence: Socioeconomic Status Affects Early Vocabulary Development via Maternal Speech. Child Development, 74, 1368-1378. http://dx.doi.org/10.1111/1467-8624.00612

Hoff, E. (2006). How Social Contexts Support and Shape Language Development. Developmental Review, 26 , 55-88. http://dx.doi.org/10.1016/j.dr.2005.11.002

Hoff-Ginsberg, E. (1991). Mother-Child Conversation in Different Social Classes and Communicative Settings. Child Development, 62, 782-796. http://dx.doi.org/10.2307/1131177

Hoff-Ginsberg, E. (1998). The Relation of Birth Order and Socioeconomic Status to Children's Language Development. Applied Psycholinguistics, 19, 603-629. http://dx.doi.org/10.1017/S0142716400010389

Küntay, A. C., \& Ahtam, B. (2004). Annelerin çocukalarıyla geçmiş hakkındaki konuşmalarının anne eğitim düzeyiyle ilişkisi (Effect of Maternal Education on Turkish Mothers' Styles of Reminiscing with Their Children). Turkish Journal of Psychology, 19, 19-31.

NICHD Early Child Care Research Network (2002). Early Child Care and Children's Development Prior to School Entry: Results from the NICHD Study of Early Child Care. American Educational Research Journal, 39, 133-164. http://dx.doi.org/10.3102/00028312039001133

Ninio, A. (1980). Ostensive Definition in Vocabulary Learning. Journal of Child Language, 7, 565-573. http://dx.doi.org/10.1017/S0305000900002853

Pancsofar, N., \& Vernon-Feagans, L. (2006). Mother and Father Language Input to Young Children: Contributions to Later Language Development. Journal of Applied Developmental Psychology, 27, 571-587.

http://dx.doi.org/10.1016/j.appdev.2006.08.003

Pancsofar, N., \& Vernon-Feagans, L. (2010). Fathers’ Early Contributions to Children's Language Development in Families from Low-Income Rural Communities. Early Childhood Research Quarterly, 25, 450-463. 
http://dx.doi.org/10.1016/j.ecresq.2010.02.001

Reese, E., \& Cox, A. (1999). Quality of Adult Book Reading Affects Children's Emergent Literacy. Developmental Psychology, 35, 20-28. http://dx.doi.org/10.1037/0012-1649.35.1.20

Tamis-LeMonda, C. S., Shannon, J. D., Cabrera, N., \& Lamb, M. (2004). Fathers and Mothers at Play with Their 2- and 3Year-Olds. Contribution to Language and Cognitive Development. Child Development, 75, 1806-1820. http://dx.doi.org/10.1111/j.1467-8624.2004.00818.x

Taşkın, N., \& Erkan, S. (2009). Babalara verilen eğitimin babalarin çocuklariyla ilgilenmelerine etkisi: deneysel bir çalışma (The Influence of Father Education Programs on the Levels of Father Involvement with Children: An Experimental Study). Hacettepe University Journal of Education, 37, 136-148.

Tomasello, M. (1992). The Social Bases of Language Acquisition. Social Development, 1, 67-87. http://dx.doi.org/10.1111/j.1467-9507.1992.tb00135.x

Türkay, F. (2007). Türk Annelerin ad/eylem kullanımlarının Bağlam etmeniyle ilişkisi. In Dilbilim Kurultayı Bildirileri (pp. 273-276). Mersin: Mersin Üniversitesi Yayınları.

Zevenbergen, A. A., \& Whitehurst, G. J. (2003). Dialogic Reading: A Shared Picture Book Reading Intervention for Preschoolers. In A. Van Kleeck, S. A. Stahl, \& E. B. Bauer (Eds.), On Reading Books to Children: Parents and Teachers. Mahwah, NJ: Lawrence Erlbaum. 